\title{
Owning New Jersey: Historic Tales of War, Property Disputes, \& the Pursuit of Happiness Joseph A. Grabas
}

The History Press, Charleston, SC, 2014. 192 pp., images. \$19.99 paper. ISBN: 1626196206. DOI: http://dx.doi.org/10.14713/njs.v2i1.33

Owning New Jersey by Joseph A. Grabas tells state history with a focus on land and place. From a professional title searcher's vantage point, Grabas argues that New Jersey's history is "underpinned by landownership," and therefore records of land transactions, such as deeds, mortgages, etc., are a rich source for revealing its history. Land transfers do that in the myriad detail of the chain of title and financing of each land parcel, transferred over the centuries of New Jersey's existence from person to person, each record being a snapshot in time of people and their relationships and circumstances. He also contends that such records are largely untapped for this purpose.

The book occupies a middle ground between a scholarly and a popular work; written in an informal style, but uses both primary and secondary sources. This engaging book tells largely untold tales that a general audience will appreciate, but also distinguishes itself by highlighting the value of a particular source-land records - in uncovering history. The stories he has discovered, or re-told from the perspective of land transactions, are on scales ranging from the state's general political history to one of the individual lives of New Jersey's everyday folks and elites, who were trying to get ahead by owning land. The sampling of subjects inclusively spans across geography, time, class, race and gender.

He begins with a chapter on New Jersey's nativity in the 1664 deed from the Duke of York to John Lord Berkeley and George Carteret. He reviews prior European settlement by explaining the New Netherland adventure (but omitting to mention New Sweden in the Delaware Valley). Nevertheless, that and his discussion of the English feudal system and the revolution in 
land ownership with King Henry VIII is an important and extremely interesting context for the fee simple land ownership system that was planted in the colony of New Jersey.

Next, Grabas moves to a very personal level in the "putting out" of Francis Jackson's children after his death in 1698. Though this tale is not about land per se, the indenture was an unexpected find in a Monmouth County deed book. It opens a window into how society dealt with the tragic circumstance of orphaned children.

Importantly, the author covers the troublesome topic of Native American land transfers to the English, and the unfortunate consequences of the fundamental differences in how the Indians and the English understood land ownership, a key historical lesson for understanding early New Jersey.

Grabas' special expertise in title searching shines in the chapter on the development of the land recording system in eighteenth-century New Jersey. Repeated efforts of the colonial legislature to create a practical county recording system were denied by the Crown, which explains anomalies and omissions in the recording of deeds before 1784. Grabas suggests that this resistance contributed to the litany of British interferences in colonial governance that ultimately led to the Revolutionary War.

Grabas devotes three chapters to African Americans in Fair Haven, Monmouth County. Here free blacks, together with Quaker conspirators, evaded pre-1798 slave codes which outlawed land ownership by any Black person. Descendants built homes, established a community, and tried to live the American property-owning dream, thereby gaining respectability. The thorough background of eighteenth-century slave codes is valuable in understanding the struggles and appreciating the successes of African-descended New Jerseyans. 
Other stories include: the seizure of a Loyalist's property in Hoboken, the slander of 16year-old girl in Freehold and the conviction and public humiliation of her attacker, the story behind the revenue tax stamps found on old deeds, the failed venture of a foundry worker to become a homeowner and grocer in Trenton, the downfall of a silk baron and art collector in Paterson to his twenty-seven creditors, the story of the crazy boundary between Delaware and Salem County, the other crazy boundary that gave Staten Island to New York, and the discovery of a church burying ground in a private yard.

Grabas' fifteen case studies are informative and compelling. He demonstrates that land records contain a wealth of untold New Jersey history; they do represent an important data source for historians. But the reader should know a caveat: land records contain inherent bias. They leave lots of people, and their stories, out: those who did not or could not buy land generally do not appear in these records. That does not, however, diminish the value of this book. Grabas' stories are well supported and interpreted, but he makes an occasional sweeping, unsupported statement which begs for a reference.

For example, he asserts that the desire for land, versus religious freedom, was the primary reason for the earliest settlement of New Jersey. However, this would not apply to the Dutch and Swedes, who came here to exploit the fur trade, not to settle. Nor would it apply to the initial English settlement of West Jersey by Quakers, who were indeed fleeing religious persecution. The cause of land hunger may better apply to East Jersey, into where New Englanders and New Yorkers swept in the 1660s.

Another is the notion that deeds and other land records are largely untapped. In architectural and cultural landscape history, land records are among the first to be tapped. In the New Jersey Historic Preservation Office's pamphlet, "How to Research the History of a House" 
deeds are high on the list of sources to check. The same is true in Recording Historic Structures (John A. Burns, National Park Service, 2004), the national standard for this kind of work. Historical archaeologists also make wide use of deeds. Nevertheless, other kinds of historians may not be as apt to use land records, and could find new insights there.

Finally, his contention that "the record of Indian deeds stands as the most comprehensive written account of colonial personal relationships among the English settlers and the natives of New Jersey" may indeed be true, but is this an original assertion by Grabas, or is it rooted in the body of New Jersey Indian studies?

With a minor need for more references and a few copyedits, and perhaps more inclusion of southern counties, the book achieves Grabas' goal of expanding the discussion about the importance of land ownership to the history of New Jersey, and is a useful contribution to New Jerseyana. I commend this book to general readers, historical researchers of every kind, and even to title searchers, who share Grabas' familiarity with land records, to put into context what they have seen.

\section{Janet Sheridan}

Cultural Landscape Historian and Heritage Preservation Consultant 